\title{
Gender Portrayal of English Textbooks In A State Islamic Junior High School In Gowa Regency, South Sulawesi, Indonesia
}

\author{
Siti Azisah \\ A senior lecture of the Faculty of Education and Teaching \\ Science, \\ State Islamic University Alauddin Makassar, \\ email: sitiazisah@yahoo.com.
}

\begin{abstract}
Indonesia has adopted gender equality policy by issuing a number of law including Gender Mainstreaming policy issued by the President Abdurrahman Wahid with the Presidential Instruction No. 9 year 2000. This policy was already issued 16 years ago. This paper aimed to examine the influence of gender mainstreaming policy on the textbooks used in Indonesian education as well examines the teachers' perspectives on gender roles. Several research questions were posed: Did the policy influence the gender portrayals of the English textbooks used by teachers in State Islamic Junior High School? Was any change in gender portrayals reflected in the English textbooks for all classes? In analysing textbooks. I used the content analysis with the following categories: visibility (visible or invisible); equity (balance or imbalance); stereotyped or non-stereotyped; neutral or gender based; progressive or non-progressive. The research uncover that gender mainstreaming policy has big influence on English textbooks used by the teachers in a state Islamic junior high school.
\end{abstract}


Keywords: curriculum, gender portrayal, Islamic Junior high School, teachers, school textbooks

\section{Introduction}

The term gender was originated from a series of the United Nations Women's Conferences. It could be found in the first United Nations Women's Conference in Mexico 1975 (Tiessen, 2007). It also appeared in the document of United Nations Third World conference on women in Nairobi in 1985 (Council of Europe, 1998; UNESCO, 2003). Then, it was prominence in the fourth women's conference in Beijing 1995 (Council of Europe, 1998; Rees, 2002) when the conference included the term gender in the declaration and the platform for action that called the institutions of the United Nations to incorporate gender perspective systematically into Policy making (Council of Europe, 1998, 2004). This declaration and platform for action called gender mainstreaming which is as key strategy to achieve gender equality (Bazinet, Sequeira \& Delahanty, 2006).

Indonesia, as one of the members of the United Nations, responded the declaration and undertook affirmative action by giving official support to implement gender mainstreaming. The Indonesian government put gender equality and gender justice as one of Indonesia's national development objectives in its Broad Outline of State Policy (GBHN) 1999 (Parawansa, 2000; Suryadi \& Idris, 2004).

Moreover, the Fourth President of the Republic of Indonesia, President Abdurrahman Wahid issued Presidential Instruction No. 9 on gender mainstreaming in 2000. This presidential instruction gave instructions to all levels of government, including the Ministry of National Education and the Ministry of Religion to implement gender-mainstreaming 
policy in each aspect of national development. As a consequence, Indonesian national development programs (PROPENAS) 2000 to 2004 have shown responsiveness to gender issues in many sectors, including education.

Gender responsiveness in the education sector can be seen in three main activities: scholarship grants to increase the proportion of female students from poor families participating in schooling at every level of education; the development of competency-based curriculum that is not gender biased and is gender responsive at every level of education; and accelerating the effort to reduce women's illiteracy rate (Ministry of Women's Empowerment Republic of Indonesia, 2002).

The Ministry of National Education, which has the responsibility to mainstream gender in education, has shown its commitment to the policy of gender mainstreaming by doing a number of related activities starting in 2002 (Suryadi \& Idris, 2004). The activities were advocacy and workshop for capacity building of leaders in the Ministry of National Education, round table discussion with the policy makers of the national education, analysing the policy of education including commissioning the Women's Studies Centers in the major provincial cities around Indonesia to undertake research on gender issues in education and to work with publishers, writers and illustrators for the publication of textbooks in 2004, writing gender profile in education and developing data base of gender segregated data. One of the policy has been produced is the guidelines for the implementation of gender mainstreaming in education in the national and local government (Sudarto, 2016). The writing of gender responsive teaching material was one of the implementation of gender mainstreaming. The implementation of this writing was supported by the Ministry 
of National Education where the Minister published the guidelines of implementation.

Gender portrayal in school textbooks has been studied by many scholars around the world for example, Spender and Sarah (1980), Spender (1982) Abraham (1989) in United Kingdom, Logsdon (1985), Parker (1997), Ahmad Muttali'in (2001), Azisah (2008) studied the school textbooks in Indonesia, Zittlement and Sadker (2002) in the United States. These studies uncovered that textbooks were dominated by male pictures and texts (Abraham1989, Logsdon 1985, Spender and Sarah 1980). The other finding of the studies were gender roles portrayals in school textbooks were stereotyped (Spender 1982, Logsdon 1985, Parker 1997, Muttali'in 2001). Furthermore, the studies of gender portrayal in textbooks by Azisah (2008) uncovered that there was improvement of gender portrayal in textbooks as the influence of the policy of gender mainstreaming though the improvement varied according to disciplines, the grade levels, the schools, the place of publication and the market. The analysis of gender portrayal based on the disciplines showed the social science textbooks had the highest frequency of female visibility among other subjects though these textbooks were still dominated by stereotyped gender roles. The least progressive textbooks were the local language textbooks.

These research studied on gender roles in textbooks informed the analytic framework of my study of gender portrayal in English textbooks used in a State Islamic junior High schools, in Gowa Regency South Sulawesi. There are many reasons for choosing this school. First, I know the School principal and the English teachers. Second I have supervising my students who undertook teaching practice in this school. Third, I had experience in supervising the teacher of English of 
grade seven, eight, and nine. Finally, the school is located in a short distance from my university where I work.

I chose the textbooks used for English lesson in this school level with the assumption that this subject would portray gender roles more equal compared to other subjects. I referred my assumption to the effort of the United Nations to mainstream gender equality for long time ago. Gender mainstreaming was originated from the Fourth United Nations Conference on Women in Beijing 1995.

This paper examines the influence of gender mainstreaming policy, issued 16 years ago, on the textbooks used in State Islamic Junior High School in South Sulawesi, Indonesia. The research examines the gender portrayal in teaching material. Several research questions were posed: Did the policy influence the gender portrayal of the English textbooks used by teachers? Was any change in gender portrayal reflected in the textbooks for all classes?

\section{Method of Study}

This study employed qualitative research approach by using content analysis to the textbooks used of the school. The study was conducted at one of the state owned Islamic Junior High Schools called Madrasah Tsanawiah Negeri Balang-Balang. It is located in Jalan Poros Malino, Kecamatan Bonto Marannu, Gowa Regency, South Sulawesi. The textbooks used for the English subject are all identified. But I did not study all the books. I choose only three textbooks. One textbooks for each level. The textbooks are Bright for gade 7, Bright for Grade 8 and the Headline English. 
These textbooks were chosen by the teachers with the consideration of the availability of the books to the students and they were in line with the English Sillabus of the Curriculum of 2013. Since this school has applied the 2013 curriculum since 2015.

Textbooks were chosen for analysis since textbooks are tools for education and tools for social change. As tools for education, textbooks have been the basic teaching resources, extending their means of instruction, since textbooks contain the general components of the curriculum, structure the teaching sequence and form the basis of assessment. In fact, they may play a part in selfeducation and compensate for lack of teacher qualifications. As a tool for social change, textbook contain values, norms and model of social behaviours.

\section{Framework of a nalysis}

In analysing the textbooks, teachers and students portrayal of gender roles I used the following categories: visibility (visible or invisible), equity (balance or imbalance), gender role (stereotype or non-stereotyped), language (neutral or gender- based) and whether the text and pictures were progressive or non-progressive. This framework was derived from a number of studies mentioned earlier.

First, the category of visibility (Litosseliti 2006; Spender 1982; Zittleman and Sadker 2002) was used to assess the presence of male and female representation both the text and the illustrations in textbooks and teaching material provided by teachers and gender role depiction of the students. If both males and females were depicted either together or alone (Gooden and Gooden 2001), the gender depiction was coded as male 
visible and/or female visible. Alternatively if the gender depiction only one sex and the opposite sex was absent, the depiction was coded as males invisible or females invisible. In the context of orthodox Islamic values and Bugis-Makasar culture, the depiction of women alone in is non-traditional and progressive.

The next category for the gender portrayal where both males and females were visible, was the equity of depictions with respect to balance or imbalance, that is, equal or unequal gender representation. This category was employed to assess the frequency and space allocation for males and females. Imbalance means that one particular sex was predominant (Abraham 1989; Deliyanni-kouimtzi 1992; Logsdon 1985; Spender and Sarah 1980) and the other was poorly represented in the texts and/or illustrations. For example, an imbalance would be a ratio of females to males of $1: 3$, or the opposite, 3:1. To determine the degree of balance, we analysed the sex of the central characters in the stories in the textbooks and the sex of the people who were the focus or in the foreground of the illustrations even though both males and females may have been depicted. Balance means that both genders were represented equally. If gender representation of females to males was better than a ratio of $2: 3$ the textbook was coded as balanced.

The third category was gender role: stereotyped or non-stereotyped (Gooden and Gooden 2001; Litosseliti 2006; Logsdon 1985; Muthali'in 2001; Parker 1997; Spender 1982; Stewart, Cooper, Stewart and Friedley 2003). Gender stereotype was defined by Shaw (cited in Gooden and Gooden 2001:90) as 'assumptions made about characteristics of each gender, such as physical appearance, physical abilities, attitudes, interests, or occupation.' Litosseliti (2006) 
found that 'the male characters tended to more powerful and varied occupational roles (for example, bank manager, school principal, doctor) than the female characters, who occupied the more stereotypical roles of nurse, housewives, or secretary' (Litosseliti 2006:87). Furthermore, Stewart and others (2003) discovered that in some mathematics textbooks, men were depicted as active, alert and scientific. Women were often depicted as dull and insignificant and were rarely involved in a career situation (Stewart and others 2003). On the other hand, nonstereotyped examples documented by Gooden and Gooden (2001:96) were 'female children included as dressing up as a pilot, ambulance driver, and scuba driver. One male child was seen attending a tea party and another helping with the laundry.'

Another category was gender neutral or non-sexist language. Marta Logsdon (1985) remarked that the Indonesian language does not present sexist language. The third person singular pronouns in Indonesian, dia, ia and -nya, are nongender-specific. The word dia can refer to he or she or it and nya can refer to his or her or its. Makasar and Bugis, the local languages that were included in this analysis, are, if anything, even more gender neutral than Indonesian. This is because these local languages more often use the same word when referring to males and females. For example, the word amuré in Bugis is used for both aunt and uncle whereas tante and paman are used in Indonesian.

The final category used was progressive or not progressive. This category was used to summarise the other four categories. So, a progressive textbook has both males and females visible and equally represented and is more likely to depict non-stereotyping and to use neutral language. A 
non-progressive textbook retained more than one aspect of gender bias and gender stereotyping.

\section{Gender Potrayal in Textbooks}

The English teachers in this school used textbook according their own choice. The teacher themselves decided which textbook would be used as tools for teaching. The textbook decision making was made by teachers based on the availability of the books. The books, of course, should be in line with the syllabus of English subject. The school has implemented the 2013 curriculum since 2015. The 2013 Curriculum were centralised in nature. The central government has prepared all supporting documents including syllabus and textbooks. Therefore, the 2013 curriculum were ready use curriculum. On the contrary, the curriculum KTSP (school based curriculum) were decentralised in nature. The curriculum development was teachers' responsibility. Teachers had to make syllabus, developing teaching materials and finding the appropriate textbook suitable with the syllabus.

The textbooks used by teacher of English subject in MTsN Balang-Balang were identified. I only chose three textbooks for content analysis.

\section{Passport to the World 1, A Fun and Easy English Book for Grade VII of Junior High Schools.}

The book was written by Agus Dwi Priyanto Datmika and Ida Kusuma Dewi. It was published by Platinum PT Tiga Serangkai Putra Mandiri in 2009. This book was actually written for serving the KTSP (school based curriculum) following the Regulation of the Minister of National Education No. 22, Year 
2006 about the competency standard of the school output. Although this book is old publication. The English teacher of grade VII considered it as appropriate textbooks for the English curriculum 2013. The teacher uses a few chapters from this book. In terms of gender portrayal, this book portrayed gender equally as shown in the picture below.

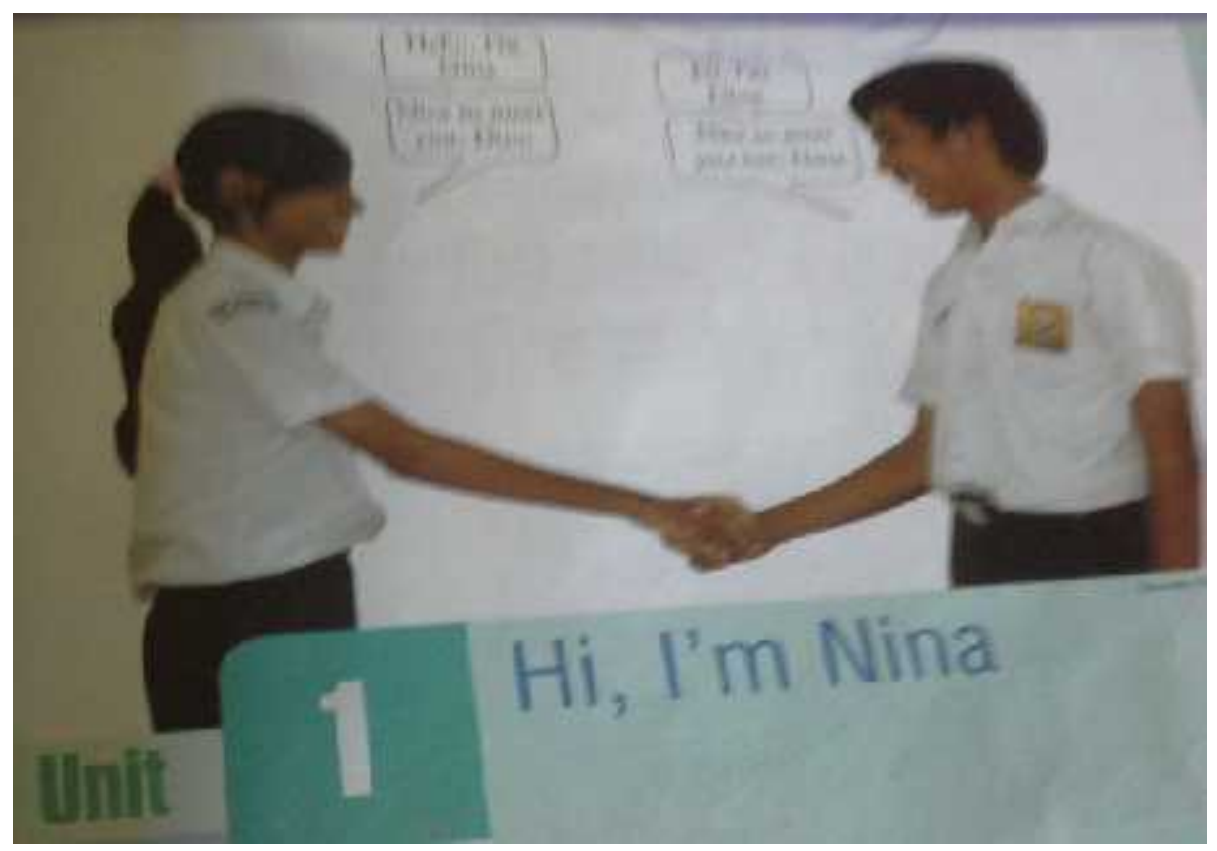

Picture 1: a boy and a girl greet each other

(Datmika and Dewi 2009)

In the picture a female and a male student greet each other. The gender portrayal shows visibility of both gender, both gender depicted equally and non-stereotyped roles and traits. The picture 2 portray males and female students. Both gender were visible. They were depicted in non-stereotyped roles and traits, yet in term of quantity, the picture was male 
dominated. The number of males in the picture was four compared with two females.

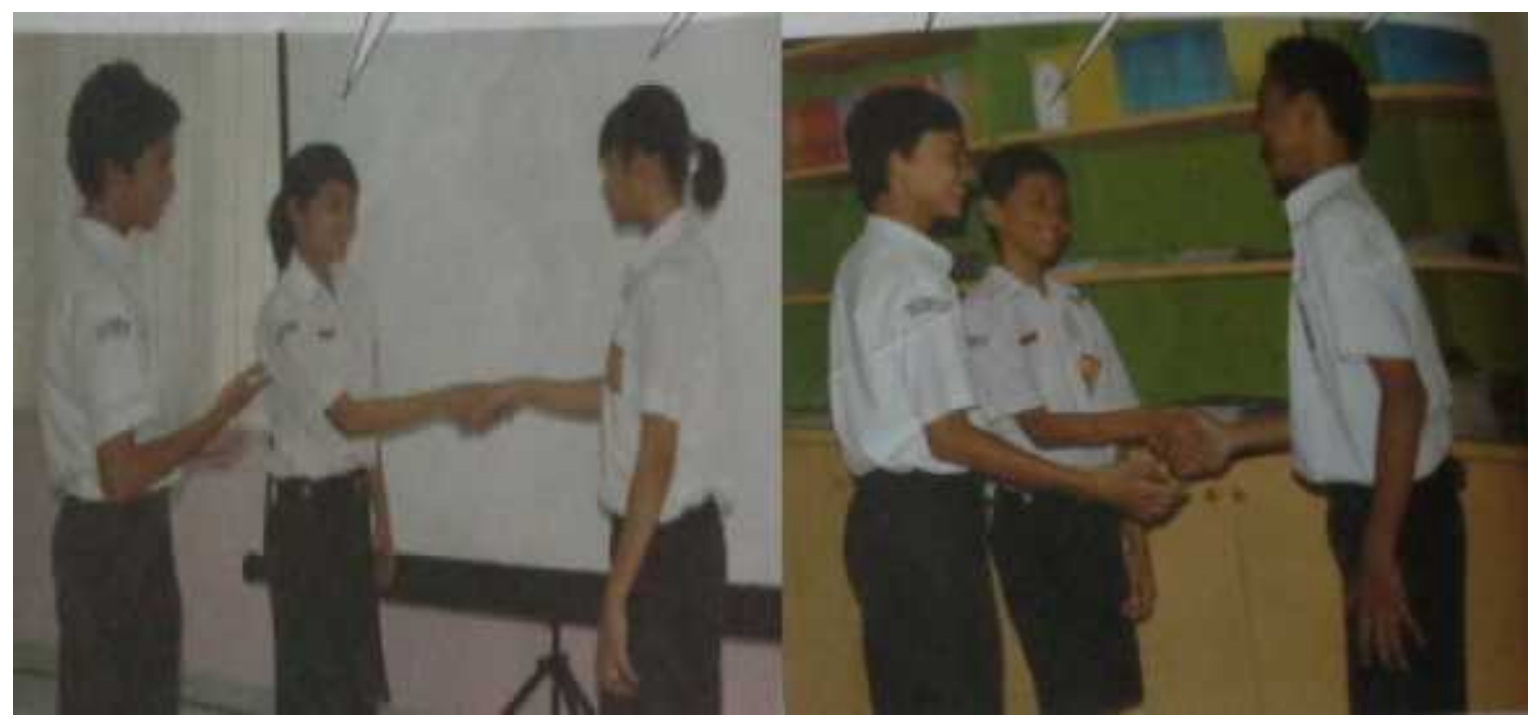

Picture 2: male and female students in the textbook ((Datmika and Dewi 2009)

Besides the pictures above, the book depicted teacher profession as non-stereotyped job. The book showed a male teacher taught junior high school students. Meanwhile, the other picture a female teacher taught in Junior high school.

\section{Bright: An English Course for Junior High School Students VIII.}

The textbook Bright was written by Nur Saida. It was published by Erlangga in 2014. The book was written for serving the 2013 curriculum. In a short look, the textbook Bright for Grade VIII portrayed gender roles equally and nonstereotyped way as shown in picture 3 . However, if we look more detail at the content of the book, we found stereotyped gender portrayal as shown in picture 4 . 


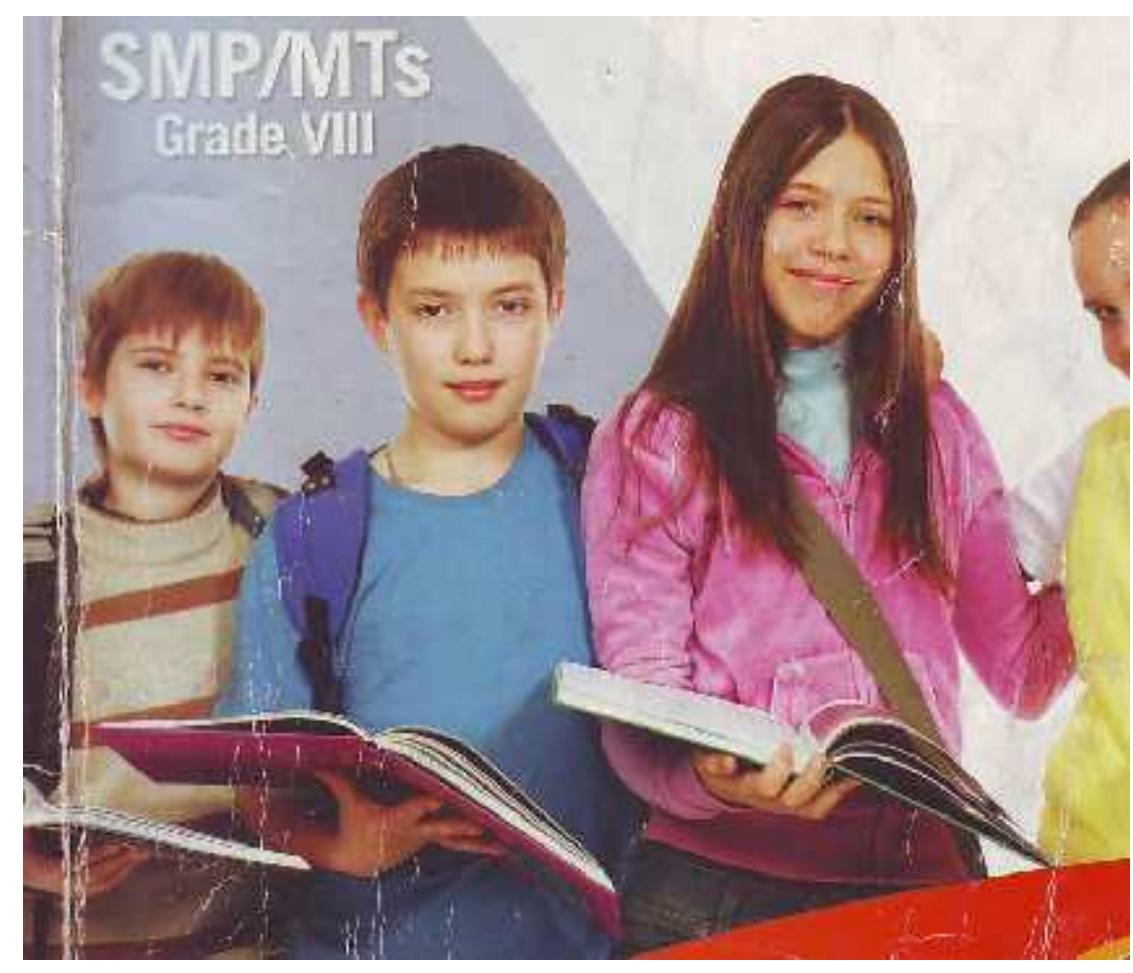

Picture 3: Males and females depicted equally and non stereotyped way (Saida, 2013) 


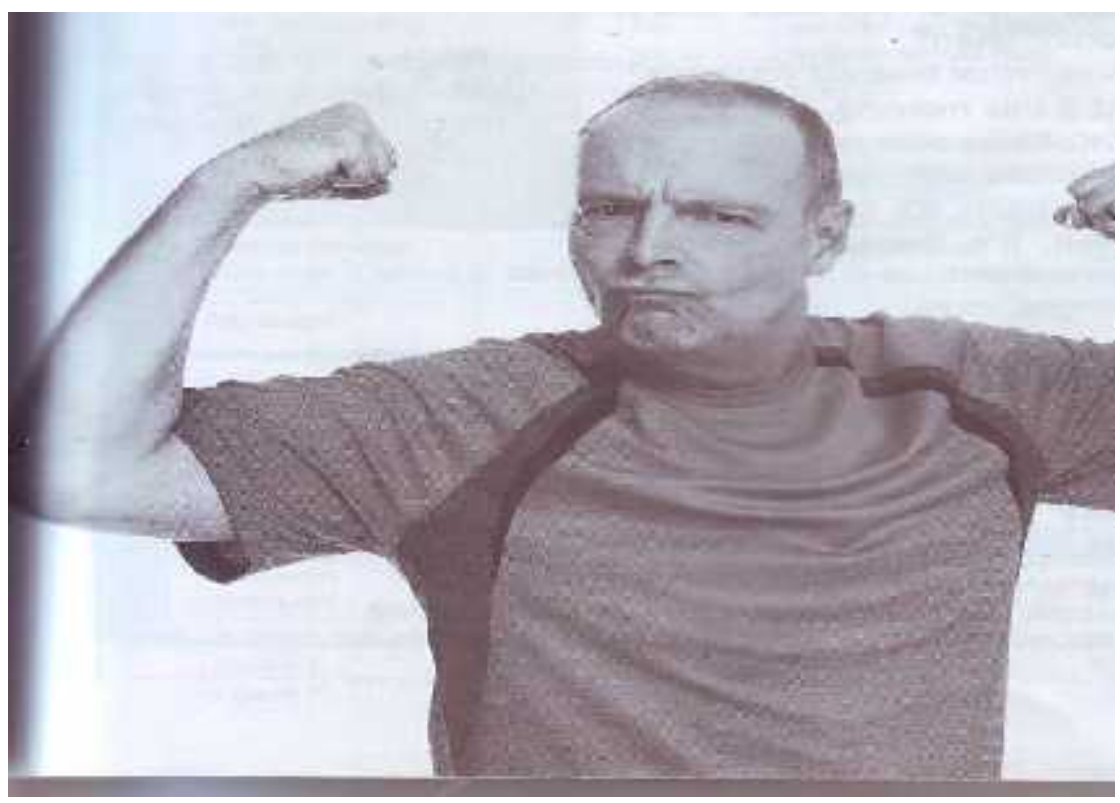

Picture 4: the textbook depicted men as strong (Saida, 2013).

The picture above shows that the man is strong as it shows the mussel of the man. This picture is gender stereotyped that a man is strong while a woman is weak. In fact, the adjective strong is not only for a man but also for a woman. Likewise, the adjective weak is not only for a woman but also for a man.

\section{Headline English for SMP-MTs 3.}

This book was aimed for serving the 2013 curriculum. It was written by M. Badrus Shaleh. In this book, both gender are mostly visible both cartoon and picture of people. The picture of people were mixed between local and foreigners. 
Many gender role depictions were non stereotyped gender roles. They were a lot of equal gender representation such as in picture 5 .

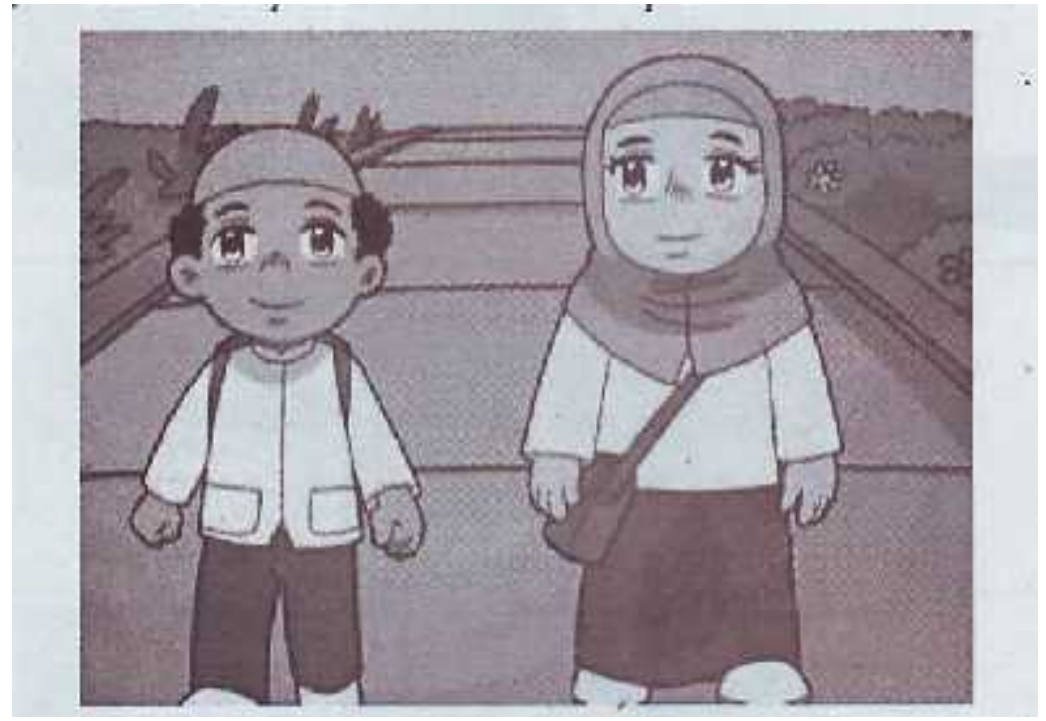

Picture 5: A boy and a girl are walking to school (Shaleh).

Nevertheless, the book also portray some stereotyped gender roles as the picture 6 and 7 


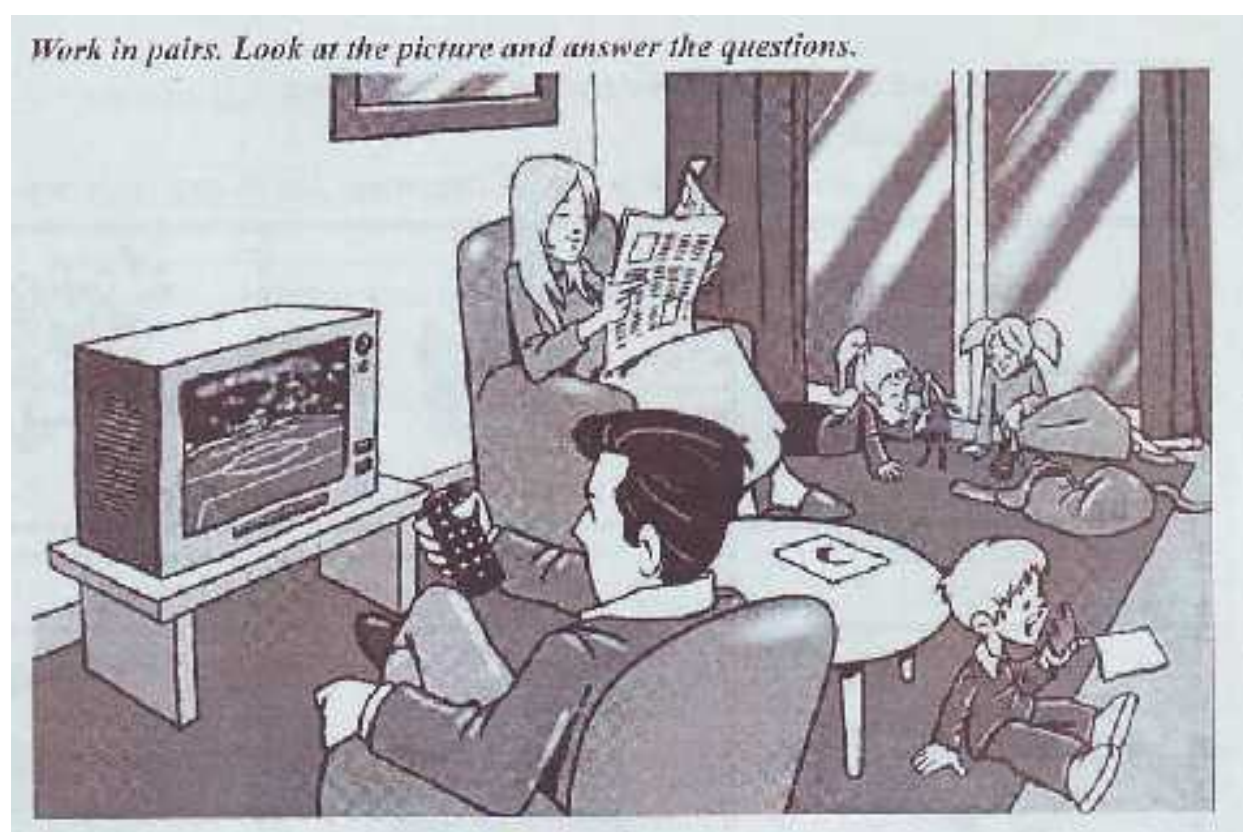

Picture 6: Gender in a family (Sholeh).

Picture six shows gender roles in the family. Each member of the family does his/her own activity. The picture of the mother and the father are doing non-stereotyped activity, the father is watching television program, while the mother is reading newspaper. Yet, the son and daughters are playing different game and toys. The girls are playing doll while the boy are playing different kind of game. 

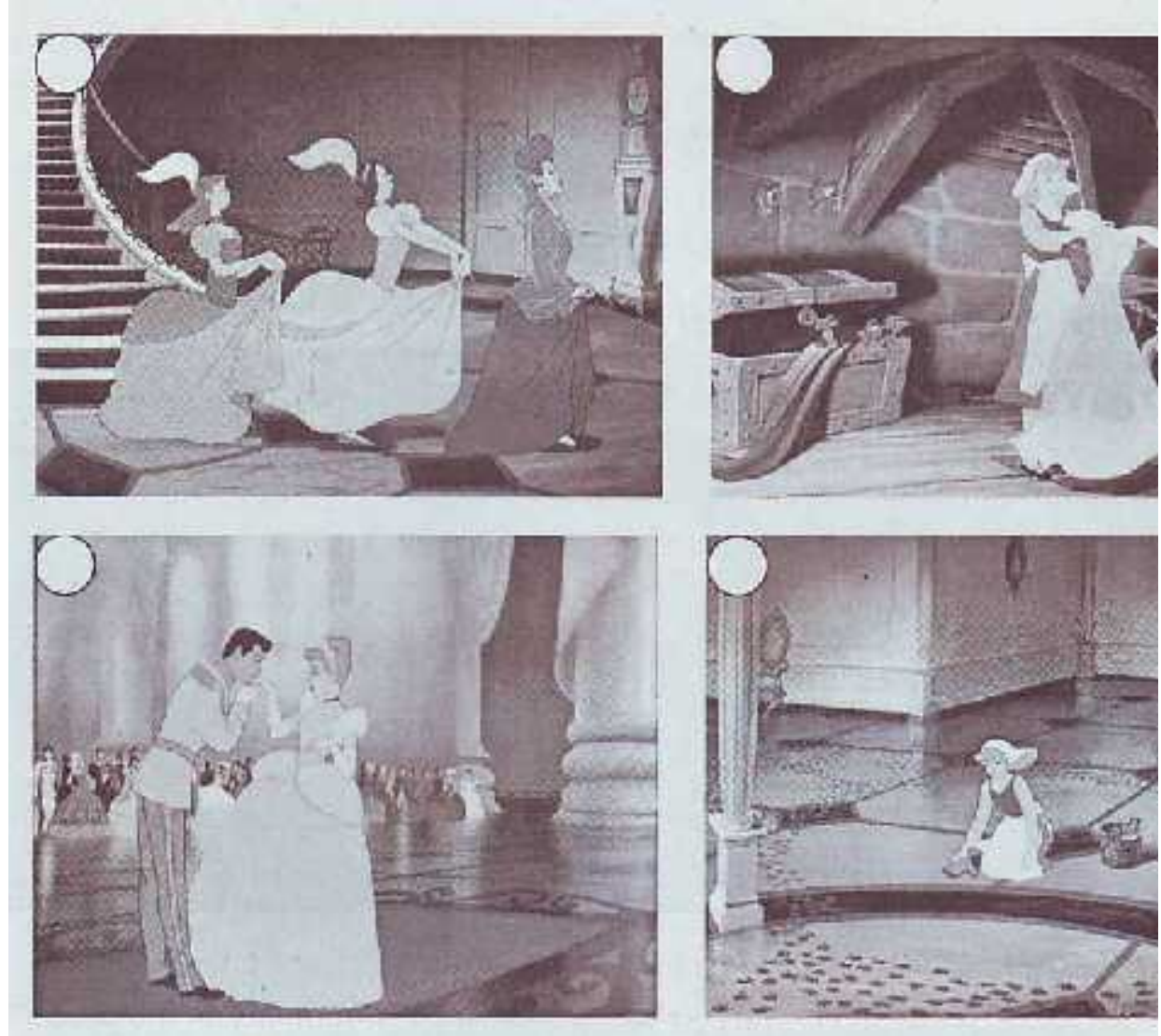

Picture7: The Pictorial Story of Cinderella (Sholeh)

Picture 7 is a serial picture of a narrative story.

Although, the story is predominated females, this story depicted gender roles in stereotyped way. The main female character are depicted playing entertainer roles namely dancing. Besides, the female was portrayed doing domestic job.

\section{Conclusion}


The textbook used by teachers of English in a State Islamic Junior High School (MTSN) depicted gender roles. Both gender are visible in textbooks. The book portray male and female equally in many images. The image of the book also depicted a lot of non-stereotyped gender roles. Yet, there are still some stereotyped gender role images.

\section{Textbooks analysed}

Datmika, Agus Dwi Priyanto and Dewi, Ida Kusuma. Passport to the World 1, A Fun and Easy English Book for Grade VII of Junior High Schools. Platinum PT Tiga Serangkai Putra Mandiri in 2009.

Saida, Nur. Bright: An English Course for Junior High School Students VIII. Erlangga in 2014.

Sholeh, M Badrus. Headline English for SMP-MTs 3. Bandung: Yrama Widya. 2016.

\section{References}

Abraham, J 1989, 'Teacher Ideology and Sex Roles in Curriculum Texts', British Journal of Sociology of Education, vol. 10, no. 1, pp. 33-51. 
Azisah, Siti (2010) "Gender Mainstreaming Policy in a State Primary School in Bone District: An analysis of Gender Roles". In Jurnal Pengkajian dan Pengembangan Ilmu Pendidikan Islam dan Sosial, 20th Ed. Vol.VIII, JulyDecember 2010, pp.140-152.

Azisah, Siti (2013) Gender roles in Islamic Primary Schools in South Sulawesi. Journal of Islamic Civilisation in Southeast Asia. Vol.2, Number 1 June 2013, pp. 137164.

Azisah, Siti (2014) Guru dan pengembangan Kurikulum Berkarakter: Implementasi pada Tingkat Satuan Pendidikan (Teacher and Curriculum Development including Affective Aspect: The Implementation in School level). Alauddin University Press, Makassar.

Azisah, Siti 2012 "Gender Mainstreaming in Education: Case Study of Islamic Primary Schools in South Sulawesi, Indonesia 2000-2006". Dissertation for Doctor of Philosophy, School of Sosial Science and Psychology, Faculty of Arts, Education and Psychology

Azisah, Siti dan Vale, Colleen 2008 "Gender Mainstreaming in Islamic Primary Schools in South Sulawesi, Indonesia: A textbook analysis" in Review of Indonesian and Malaysian Affairs, Vol. 42, No. 1, pp. 55-79. 
Denzin, NK \& Lincoln, YS 1998, The Landscape of Qualitative Research: Theories and issues, Handbook of qualitative research pbk. edn, Sage Publications, Thousand Oaks, Calif.

Litosseliti, L 2006, Gender and Language: Theory and Practice, Hodder Arnold, New York.

Spender, D \& Sarah, E 1980, Learning to Lose: Sexism and Education, The Women Press, Great Britain.

Spender, D 1982, Invisible Women: The Schooling Scandal, Writers and Readers Publishing Cooperative Society Ltd, England.

Sudarto, Subi 2016, "Hasil Capaian Pengarus Utamaan Gender Bidang Pendidikan" http://www.paudni.kemdikbud.go.id/bindikmas diakses pada tanggal 15/02/2016

Sunarti 2004, 'Gender dan Pendidikan Dasar; Studi Kasus Representasi Gender dalam Pembelajaran Bahasa Indonesia di SDN Kota Banjarmasin '(Gender and 
Primary School: A case study of gender representation in the teaching of Indonesian Language), Fakultas Keguruan dan Ilmu Pendidikan Univesitas Lambung Mangkurat.

Suryadi, A \& Idris, E 2004, Kesetaraan Gender dalam Bidang Pendidikan, Ganesindo, Bandung.

Yenowitz, KL \& Weather, KJ 2004, 'Do Boys and Girls Act Differently in the Classroom? A Content Analysis of Student Characters in Educational Psychology Textbooks', Sex Roles, vol. 51, no. 1/2, pp.

Zittleman, K \& Sadker, D 2002, 'Gender Bias in Teacher Education Texts New (and Old) lessons', Journal of Teacher Education, vol. 53, no. 2, pp. 168-80. 